\title{
GENDER EFFECT ON THE CLINICAL MEASUREMENT OF SWALLOWING
}

\author{
Leda Maria Tavares ALVES, Rachel de Aguiar CASSIANI, Carla Manfredi dos SANTOS and \\ Roberto Oliveira DANTAS
}

\begin{abstract}
Background - Swallowing coordination is affected by cortical and subcortical inputs from the central nervous system. Our hypothesis is that the swallowing dynamics may be influenced by gender. Aim - To evaluate the influence of gender on water swallowing dynamics. Methods - We studied 111 health subjects, 36 men, aged 24-77 years (mean: $46.3 \pm 16.1$ years) and 75 women, aged 2275 years (mean: $39.6 \pm 13.3$ years). All volunteers swallowed in triplicate $50 \mathrm{~mL}$ of water at $4^{\circ} \mathrm{C}$ while precisely timed, when we measured the time to swallow all the volume and counted the number of swallows. We calculated the inter-swallow interval: the time to complete the task, in seconds, divided by the number of swallows; swallowing velocity: volume drunk $(\mathrm{mL})$ by the time taken (s); swallowing volume capacity: volume drunk $(\mathrm{mL})$ divided by the number of swallows. Results - Women had a shorter inter-swallow interval, slower swallowing velocity and lower volume capacity than men. Conclusion - Gender has an effect on water swallowing dynamics, with women having a lower swallowing velocity and a lower volume capacity in each swallow than men.
\end{abstract}

HEADINGS - Deglutition. Gender identity. Drinking.

\section{INTRODUCTION}

Swallowing is an activity that involves a complex sequential sensorimotor mechanism, with both volitional and reflexive components ${ }^{(4)}$. Impairment of swallowing is often followed by multiple complications, including aspiration pneumonia, malnutrition, dehydration and weight loss ${ }^{(18)}$.

The physiological control of swallowing is done by the swallowing center, a complex organization of neural elements in the brainstem that is required to initiate and to coordinate the neuromuscular interactions that are involved in swallowing ${ }^{(3,5)}$. Although cortical and subcortical inputs are not required for the pharyngeal and esophageal swallowing they influence the coordination of the events ${ }^{(5)}$.

The oral swallow depends on a combination of voluntary and involuntary control of the position of lips, teeth, jaw, cheeks, and tongue ${ }^{(3)}$, and on the variables of the swallowed bolus ${ }^{(6)}$. This control may have differences caused by gender.

Our aim in this paper was to evaluate the effect of gender on water swallowing, using the timed swallowing test $^{(2,4,10)}$.

\section{METHODS}

We studied 111 healthy subjects without swallowing complaints, without neurological diseases, with no previous surgery in the upper gastrointestinal tract, and with body mass index (BMI) less than $40 \mathrm{~kg} / \mathrm{m}^{2}$ (Table 1). They were 36 men, aged 24-77 years (mean: $46.3 \pm 16.1$ years), and 75 women, aged $22-75$ years (mean: $39.6 \pm 13.3$ years). The study was approved by the Human Research Committee of the University Hospital of Ribeirão Preto, SP, Brazil. Written informed consent was obtained from all participants.

To evaluate swallowing we used the swallowing drink test previously described ${ }^{(2,4,10)}$. All subjects were evaluated in the sitting position. They were asked to drink $50 \mathrm{~mL}$ of water at $4^{\circ} \mathrm{C}$ from a plastic cup "as quickly and as comfortably as possible" while being precisely timed. The chronometer was started when the first drop of water touched the lip, and was stopped when the larynx of the volunteers came to rest and they breathed ${ }^{(4)}$. The volunteer performed sequential swallows without any breaks for breathing during each measurement. The swallowing test was performed in triplicate, with an interval between measurements of at least 30 seconds. All four researchers involved in the project had previous training in timing the swallows and counting the number of swallows, determined from the number of upper movements of the larynx. Each measurement was performed in the presence of at least two researcher. They had to agree in the moment of start and stop the chronometer and agree in the number of swallows.

In addition to the time and number of swallows needed to ingest $50 \mathrm{~mL}$ of water we calculated: a) inter-swallows interval: the time to complete the task, in seconds, divided by the number of swallows during

Clinical Departament, São Paulo University School of Medicina, Ribeirão Preto, SP, Brazil

Correspondence: Dr. Roberto Oliveira Dantas - Departamento de Clínica Médica - Faculdade de Medicina de Ribeirão Preto - USP - 14049-900 - Ribeirão Preto, SP. E-mail: rodantas@fmrp.usp.br 
the task; b) swallowing velocity: volume drunk ( $\mathrm{mL})$ divided by the time taken, in seconds; swallowing volume capacity: volume drunk $(\mathrm{mL})$ divided by the number of swallows.

We compared the results of men and women. The statistical analysis was performed at the Center of Quantitative Methods (CEMEQ) of the Medical School of Ribeirão Preto, with a linear model of multiple effects and the PROC Mixed of the SAS software version 9. The differences were considered significant when $P<0.05$. The results are shown in mean $\pm \mathrm{SD}$ and median.

\section{RESULTS}

Comparisons of men and women revealed a shorter inter-swallow interval, slower swallowing velocity and lower volume capacity in women (Table 2, $P<0.05$ ). There was no influence of height on the swallowing measurements $(P>0.18)$, considering that the men were taller $(1.71 \pm 0.08 \mathrm{~m})$ than women $(1.62 \pm 0.06 \mathrm{~m})$. There was also no influence of BMI $(P>0.16)$ and age $(P>0.15)$.

\section{DISCUSSION}

The results showed that women have a different swallowing dynamic compared with men. The ageing process, at least before 70 years, the BMI less than $40 \mathrm{~kg} / \mathrm{m}^{2}$ and height had no effect on this dynamic.

A previous study showed that, in healthy adults, average volume per swallow (volume capacity) and swallowing capacity (swallowing velocity) were greater in men than in women ${ }^{(10)}$, with a decline in both average volume per swallow and swallowing capacity being observed with ageing ${ }^{(10)}$. An effect of age on swallowing was described in the pharynx ${ }^{(8,10)}$ and esophagus ${ }^{(1,9)}$, suggesting that the ageing process may alter the pharyngeal and esophageal function at an advanced age. Only nine of our volunteers had ages ranged from 70 to 77 years, when the effect of the aging process is more frequently seen ${ }^{(10)}$.
The difference between men and women might be related to a larger oral and pharyngeal cavity in men, allowing a large bolus volume to be swallowed. We did not find a correlation between height and any of the five variables measured. A previous study also found that height has little influence on swallowing ${ }^{(10)}$. It was observed difference between men and women in the duration of upper esophageal sphincter opening, with females having a longer opening duration, what may be a compensation for anatomic differences ${ }^{(11,16)}$.

The duration of oropharyngeal pressure is affected by age, gender and bolus type. Women have a longer duration of oropharyngeal pressure compared with men ${ }^{(15)}$. In the esophagus after wet swallows the duration of contractions is higher in women than in men at $5 \mathrm{~cm}$ above the lower esophageal sphincter, and the velocity of contractions in the middle esophagus is higher in men than in women, also with wet swallows ${ }^{(7)}$. Oropharyngeal perceptions of fluid viscosity deteriorates with increasing age, with men exhibiting a more marked deterioration in sensitivity than women ${ }^{(17)}$.

Other possible explanations might be differences in coordination of swallowing and breathing, and differences in sensory input causing differential effects on swallowing physiology ${ }^{(4)}$. This input is conveyed via three cranial nerves innervating the muscles of swallowing and includes the trigeminal nerve, the glossopharyngeal nerve and the vagus nerve, whose superior laryngeal branch appears to be the most important for swallowing ${ }^{(3,5)}$. To our knowledge, there is no evidence that the activity of these nerves, or the coordination between breathing and swallowing, differs between men and women. With swallows of a larger volumes of water (100 or $150 \mathrm{~mL}$ ) than used here it is also possible to see differences between men and women in the volume capacity and swallowing velocity ${ }^{(10)}$. When the water drinking test was performed immediately after oral anesthesia no alteration in volume (swallowing) capacity, a decrease in swallowing velocity, and

TABLE 1. Characteristics of the subjects included (mean \pm SD)

\begin{tabular}{lcccc}
\hline & Number & Age (years) & $\begin{array}{c}\text { Weight } \\
(\mathrm{kg})\end{array}$ & $\begin{array}{c}\text { Height } \\
(\mathrm{m})\end{array}$ \\
\hline Men & 36 & $46.3 \pm 16.1$ & $81.4 \pm 13.9$ & $1.71 \pm 0.08$ \\
Women & 75 & $39.6 \pm 13.3$ & $70.9 \pm 19.2$ & $27.8 \pm 4.9$ \\
\hline
\end{tabular}

$\mathrm{BMI}$ - body mass index

TABLE 2. Effect of gender on swallowing measurements

\begin{tabular}{|c|c|c|c|c|c|}
\hline & \multicolumn{2}{|c|}{ Men } & \multicolumn{2}{|c|}{ Women } & \multirow[b]{2}{*}{$P$} \\
\hline & Mean \pm SD & Median & Mean \pm SD & Median & \\
\hline $\begin{array}{l}\text { Swallowing } \\
\text { duration (s) }\end{array}$ & $5.17 \pm 2.24$ & 4.46 & $5.54 \pm 1.72$ & 5.13 & 0.232 \\
\hline $\begin{array}{l}\text { Number of } \\
\text { swallows }\end{array}$ & $3.79 \pm 1.78$ & 3.00 & $4.47 \pm 1.27$ & 4.00 & 0.001 \\
\hline $\begin{array}{l}\text { Inter-swallow } \\
\text { Interval (s) }\end{array}$ & $1.51 \pm 0.82$ & 1.36 & $1.26 \pm 0.32$ & 1.21 & 0.013 \\
\hline $\begin{array}{l}\text { Swallowing } \\
\text { velocity }(\mathrm{mL} / \mathrm{s})\end{array}$ & $11.30 \pm 4.22$ & 11.22 & $9.93 \pm 3.20$ & 9.75 & 0.045 \\
\hline Volume capacity (mL) & $16.84 \pm 9.79$ & 16.66 & $12.05 \pm 3.43$ & 12.5 & 0.001 \\
\hline
\end{tabular}


an increase in inter-swallow interval was observed compared to the baseline period without anesthesia ${ }^{(4)}$, showing that efferent inputs have an important role in the coordination of swallowing. Sensitivity is the explanation for the influence of the volume and consistency of the bolus on the oral and pharyngeal phases of swallowing ${ }^{(6)}$.

The swallowing drinking test measures water ingestion and can separate patients with dysphagia at the level of disability from subjects without swallowing problems, but does not provide information about the nature or severity of the disease ${ }^{(12,13,14)}$. The test has good intra-individual reproducibility ${ }^{(2)}$ but cannot be used to directly study aspiration risk $^{(10)}$. It is easy to perform and is an inexpensive way to evaluate swallowing ${ }^{(2)}$.
The differences between men and women we found during the test may be important for the clinical treatment of dysphagia, which must consider these differences. It is possible that during recovery from a stroke women eat more slowly, with an increased number of swallows to eat a meal and having to receive a smaller bolus volume each time, when compared with a man in a similar situation. Women with an apparently more important disability during swallowing may not have a more intense compromise of the swallowing mechanism, but this apparent more important disability may be only an influence of gender. Further investigations is needed to test this hypothesis.

In conclusion, we found a gender effect on water swallowing dynamics, with women having a lower swallowing velocity and a lower volume capacity in each swallow than men.

Alves LMT, Cassiani RA, Santos CM, Dantas RO. Influência do gênero em parâmetros da deglutição. Arq Gastroenterol. 2007;44(3):227-9.

RACIONAL - Resumo - O controle da coordenação da deglutição é influenciado por estímulos corticais e subcorticais do sistema nervoso central. A hipótese deste estudo é de que a dinâmica da deglutição possa ser influenciada pelo gênero. Objetivo - Avaliar a influência do gênero na dinâmica da deglutição. Método - Estudaram-se 111 pessoas consideradas normais, 36 homens com idades entre 24 e 77 anos, média de 46,3 $\pm 16,1$ anos, e 75 mulheres com idades entre 22 e 75 anos, média de 39,6 $\pm 13,3$ anos. Todos os voluntários ingeriram $50 \mathrm{~mL}$ de água na temperatura de $4^{\circ} \mathrm{C}$, sendo medido o tempo para ingerir todo o volume e contado o número de deglutições. Foi calculado o intervalo entre as deglutições: o tempo (em segundos) para ingerir todo o volume dividido pelo número de deglutições; velocidade de ingestão: volume ingerido $(\mathrm{mL})$ dividido pelo tempo de ingestão (s); volume de cada deglutição: volume total ingerido (mL) dividido pelo número de deglutições. Resultados - Foi observada nas mulheres menor duração do intervalo entre deglutições, menor velocidade de ingestão e menor volume ingerido em cada deglutição, quando comparado com os homens. Conclusão - Gênero tem influência na dinâmica da deglutição de água, com as mulheres tendo menor velocidade de ingestão e menor volume em cada deglutição, quando comparadas com os homens.

DESCRITORES - Deglutição. Identidade de gênero. Ingestão de líquidos.

\section{REFERENCES}

1. Achem SR, Devault KR. Dysphagia in aging. J Clin Gastroenterol. 2005;39: 357-71.

2. Alves LM, Cassiani RA, Santos CM, Dantas RO. Avaliação da deglutição pelo teste de ingestão de água. GED Gastroenterol Endosc Dig. 2007;26:1-4.

3. Bass NH. The neurology of swallowing. In: Groher ME, editor. Dysphagia-diagnosis and management. 3rd ed. Boston: Butterworth-Heinemann; 1997. p.7-35.

4. Chee C, Arshad S, Singh S, Mistry S, Hamdy S. The influence of chemical gustatory stimuli and oral anaesthesia on healthy human pharyngeal swallowing. Chem Senses. 2005;30:393-400.

5. Conklin JL, Christensen J. Motor functions of the pharynx and esophagus. In: Johnson LR, editor. Physiology of the gastrointestinal tract. 3rd ed. New York: Raven Press; 1994. p.903-28.

6. Dantas RO, Kern MK, Massey BT, Dodds WJ, Kahrilas PJ, Brasseur JG, Cook IJ, Lang IM. Effect of swallowed bolus variables on oral and pharyngeal phases of swallowing. Am J Physiol. 1990;258:g675-81.

7. Dantas RO, Ferriolli E, Souza MA. Gender effects on esophageal motility. Braz J Med Biol Res. 1998;31:539-44.

8. Dejaeger E, Pelemans W, Bihau G, Ponette E. Manofluorographic analysis of swallowing in the elderly. Dysphagia. 1994;9:156-61.

9. Ferriolli E, Dantas RO, Oliveira RB, Braga FJ. The influence of ageing on oesophageal motility after ingestion of liquids with different viscosities. Eur J Gastroenterol Hepatol. 1996;8:793-8.
10. Hughes TA, Wiles CM. Clinical measurement of swallowing in healthy and in neurogenic dysphagia. QJM. 1996;89:109-16.

11. Logemann JA, Pauloski BR, Rademaker AW, Kahrilas PJ. Oropharyngeal swallow in younger and older women: videofluoroscopic analysis. J Speech Lang Hear Res. 2002;45:434-45.

12. Nathadwarawala KM, Nicklin J, Wiles CM. A timed test of swallowing capacity for neurological patients. J Neurol Neurosurg Psychiatry. 1992;55:822-5.

13. Nathadwarawala KM, McGroary A, Wiles CM. Swallowing in neurological outpatients Dysphagia. 1994;9:120-9.

14. Nicklin J, KomiY, Wiles CM. Measurement of swallowing time - a proposed method. Clinical Rehabilitation. 1990;4:335-6.

15. Perlman AL, Schultz JG, Van Daele DJ. Effect of age, gender, bolus volume, and bolus viscosity on oropharyngeal pressure during swallowing. J Appl Physiol. 1993;75:33-7.

16. Robbins JA, Hamilton JW, Lof GL, Kempster GB. Oropharyngeal swallowing in normal adults of different ages. Gastroenterology. 1992;103:823-9.

17. Smith CH, Logemann JA, Burghardt WR, Zecker SG, Rademaker AW. Oral and oropharyngeal perceptions of fluid viscosity across the age span. Dysphagia. 2006;21:209-17.

18. Smithard D, O’Neill P, Parks C, Morris J. Complications and outcome after acute stroke: does dysphagia matter? Stroke. 1996;27:1200-4. 